\title{
Does Information Lead to Emulation? Spatial Dependence in Anti-Government Violence
}

\author{
BLAKE E. GARCIA AND CAMERON WIMPY
}

\begin{abstract}
7 his study examines whether acts of anti-government violence exhibit spatial dependence across state boundaries. In other words, to what extent can acts of anti-government violence in one country be attributed to violence in neighboring countries? Past research, which has largely focused on civil war or large-scale conflict contagion, finds that geographically proximate states are more likely to experience the cross-boundary diffusion of conflict due to action emulation. However, this assumes that actors are fully aware of conflicts occurring in neighboring countries. To address this, the article argues that the proliferation of communication technology increases access to information about events in neighboring states, thereby allowing emulation to occur and subsequently conditioning the potential for violence to spread. It tests this expectation by modeling the effects of a unique spatial connectivity matrix that incorporates both state contiguity and access to communication technology. An analysis of all acts of anti-government violence in 44 African countries from 2000 to 2011 supports the argument.
\end{abstract}

$\mathrm{I}$ this article we study the spread of anti-government violence across international boundaries. Specifically, we examine whether communications technology can facilitate spatial dependence in anti-government violence as it moves from one country to one or more neighbors. Technology certainly allowed the events of the Arab Spring to spread very rapidly, often across international borders (Lotan et al. 2011; Stepanova 2011). Little attention, however, has been paid to the mechanisms that allow these spatial relationships to occur. We demonstrate that this process has been slowly taking place for more than a decade in Africa. Our findings suggest that increasing interconnectivity from communications technology can facilitate the spread of anti-government violence from one country to another.

Past research, which most often examines the spread of larger-scale conflicts, such as domestic armed conflicts and civil wars, argues that diffusion across state boundaries occurs because actors observe the events occurring in a neighboring country and emulate those actions against their own government (Anselin and O'Loughlin 1992; Gleditsch 2002; Braithwaite 2006, 2010; Buhaug and Gleditsch 2008; Maves and Braithwaite 2013). However, these analyses assume that actors within one country are always more likely to be aware of the violent events occurring in their neighbor, rather than some more distant state, simply because they share a border. Thus adjacency matrices that attempt to capture spatial dependence in conflicts do not incorporate actors' potential variation in awareness of neighboring events, thereby potentially overestimating the degree of dependence. We argue that in order to emulate violent events in neighboring countries, actors must become aware of these events through their exposure to information about them.

Blake E. Garcia is a Ph.D. Candidate and Cameron Wimpy is a Post-Doctoral Fellow in the Department of Political Science at Texas A\&M University, 2010 Allen Building, College Station, TX 77843-4348 (b.garcia@pols.tamu.edu, cwimpy@pols.tamu.edu). We thank Jude Hays, Guy Whitten and the participants of the Spatial Models of Politics conference at Texas A\&M for comments on an earlier version of this article. We also thank two anonymous reviews for their thoughtful comments. Any errors are our own. 
We make three contributions to the literature. First, we elucidate the commonly discussed (but as yet unmodeled) assumption that access to information concerning events across geographical boundaries allows for the theoretical diffusion mechanism of emulation to occur across those boundaries. Second, we attempt to directly model this access to information instead of assuming that state contiguity alone captures emulation behavior. Third, we apply these constructs to explain the spread of anti-government violence rather than the more common outcomes of domestic armed conflicts and civil wars. Examining low-intensity acts of government violence rather than larger sustained and organized mass rebellions provides a harder test of our theory due to the lower likelihood that displaced populations and refugees will spread news by word of mouth.

Our methodological contribution is somewhat unique in the spatial econometrics literature, in that we allow spatial dependence to be conditioned by our primary explanatory variables. This approach allows the researcher to analyze more connectivity information in the spatial modeling process than is ordinarily possible. This is especially useful in the absence of measurable connectivity outside of geographic boundaries and distance. Conditioning the spatial dependence also relates to our theoretical contribution, in that we attempt to properly model our theorized channel of connectivity between units, in this case countries.

The article proceeds in several sections. We first review the literature on the spread of violence. Second, we detail our theoretical contribution regarding the role of information acquisition in spatial dependence. Third, we introduce our data and modeling procedure. We then explain our data sources and research design, and discuss our empirical results. The final section concludes by highlighting the potential implications of our findings and suggestions for future work.

\section{THE SPREAD OF VIOLENCE}

There is growing and increasingly compelling evidence that numerous forms of violent conflict are not independent, isolated phenomena. Rather, they exhibit non-random spatial distribution patterns that suggest a high degree of interdependence. In other words, conflict behavior at the sub-state level has the potential to spread across state boundaries and act as a form of contagion. The vast majority of conflict contagion analyses specifically examines large-scale domestic armed conflict and civil wars (Anselin and O'Loughlin 1992; Gleditsch 2002; Braithwaite 2006, 2010; Buhaug and Gleditsch 2008; Salehyan and Gleditsch 2006; Maves and Braithwaite 2013). However, evidence also exists for the spread of protests and rioting behavior (Govea and West 1981; Hill and Rothchild 1986; Hill, Rothchild and Cameron 1998; Myers 2000) as well as international terrorism (Midlarsky, Crenshaw and Yoshida 1980; Braithwaite and Li 2007; Neumayer and Plümper 2010; Cliff and First 2013).

In order to examine the extent to which anti-government violence in a neighboring country increases the probability of anti-government violence at home, one must overcome two hurdles. First, we make the distinction between outcomes that are spatially dependent on one another and those that occur due to similar underlying causes. Are there circumstances in which violence is truly spatially dependent, or are we simply observing similar outcomes that geographically cluster together because these countries exhibit similar underlying factors that raise the risk of violence? This is known as Galton's problem (Galton 1889). In other words, are acts of violence against the government occurring in one's own country dependent on similar acts of violence occurring in a prior time period abroad? Or are these acts of violence occurring due to similar domestic conditions? A second hurdle is determining the appropriate measure of dependence. Measures of interstate contiguity, length of shared borders and distances between state capitals are all different ways of capturing geographic proximity, and have all displayed evidence of interdependence (Anselin and O'Loughlin 1992; Murdoch and Sandler 2002). 
However, Buhaug and Gleditsch (2008) find that geographic proximity, regardless of how it is measured, only minimally influences civil conflict contagion. Instead, they find that transnational ethnic ties, as well as similar political regimes and underlying economic conditions that make countries more prone to conflict at the outset, are more significantly driving the geographic clustering of conflict. Similarly, Salehyan and Gleditsch (2006) show that the negative externalities associated with civil conflicts, such as the migration of refugees and movement of weapons, flow from conflict zones into neighboring countries. Although these findings might be interpreted as countering spatial dependence arguments, they still demonstrate that geographical proximity allows for transboundary movements of the negative externalities resulting from one state's conflict, raising the risk of conflict in a proximate state. These effects would then be less likely to occur the farther away a state is from the conflict-ridden state.

More recent evidence for spatial dependence utilizes government characteristics as a conditioning factor. Braithwaite (2010) finds that higher levels of state capacity reduce the likelihood of conflict contagion due to the government's enhanced ability to buffer the spread of violence. Therefore, large-scale organized conflicts against the government should only be able to spread from a neighboring country when one's own government is unable to contain the violence. Maves and Braithwaite (2013) examine the institutional design of autocratic regimes as a conditioning factor to the spread of civil conflict. They find that autocratic countries with legislatures are more likely to experience their own war when conflict is occurring in a neighboring country. This is because of both negative externalities resulting from the neighbor's conflict and the decreased credibility of promised political reforms beyond the establishment of a legislature, which fuels domestic opposition and leads to a higher likelihood of conflict emulation.

Although empirical findings have provided fairly consistent evidence that conflict is spatially dependent, the most common mechanism by which this dependence is argued to occur, largely drawn from the policy diffusion literature, is through the emulation of actions. ${ }^{1}$ We do not disagree that the process of emulation is potentially at work. Rather, we argue that because emulation crucially depends on exposure to information regarding actions to emulate, and because this exposure to information naturally varies from country to country, the probability of contagion should be conditioned by this exposure to information.

\section{HOW INFORMATION LEADS TO EMULATION}

Two common mechanisms are used to explain the diffusion of civil conflicts across state boundaries. The first mechanism relies on a purely rational learning framework. Actors are exposed to information concerning proximate events that they then process in an unbiased manner. This unbiased information is systematically utilized to order their preferences among a set of outcomes. Actors then engage in subsequent actions that represent their ordered preferences and maximize their utility. When applying the rational learning framework to conflict diffusion, we can argue that potential opposition groups engage in a strict cost-benefit analysis when deciding whether to violently challenge their government. Learning from their observation of a successful rebellion in a neighboring country, they will emulate those actions to achieve a similar outcome at home (Lake and Rothchild 1998).

A second explanatory mechanism holds that neighboring conflicts may create a large crossborder migration of refugee populations, which could intensify resource competition and potentially shift the balance of power among competing ethnic groups in receiving countries

\footnotetext{
${ }^{1}$ See Elkins and Simmons (2005) for a review of diffusion mechanisms.
} 
(Salehyan and Gleditsch 2006; Gleditsch 2007; Buhaug and Gleditsch 2008). Sudden shifts in the distribution of resources might intensify existing frustrations and lead to a higher likelihood of rebellion (Gurr 1993). Refugees can also act as a source of information concerning conflicts from which they were displaced, revealing new choices of action for potential rebel groups, leading to subsequent spillover effects (Moore and Davis 1998; Buhaug and Gleditsch 2008).

Although these mechanisms are certainly reasonable and have made numerous contributions, particularly in the policy diffusion literature, a strict rational learning framework leaves two features of conflict diffusion unexplained. ${ }^{2}$ First, a rational learning approach would argue that acts of anti-government violence must be successful in order for neighboring opposition groups to emulate the behavior. If violence against the government is observed as being an unsuccessful policy-changing strategy by neighboring groups, then this would not maximize utility and thus would not be a preferred strategy. However, successful acts of anti-government violence rarely change government policy in favor of the opposition. Yet this does not appear to slow the rate of anti-government violence. Second, a rational learning approach suggests that actors seek to maximize their utility over outcomes by searching all available information, not just the set of actions used by potentially unrelated opposition groups in bordering countries. However, since this approach does not explain this type of bounded information seeking, this theoretical approach may be inappropriate for explaining the cross-border spread of anti-government violence. We also do not expect the spread of anti-government violence across state borders to be triggered by the flow of refugees. This mechanism should only apply to high-intensity domestic armed conflicts and civil wars, which are far more likely to produce large-scale refugee populations.

We instead choose to utilize a cognitive heuristics framework to explain the cross-border spread of anti-government violence because it allows us to resolve the above-mentioned shortcomings of the purely rational learning approach in our specific context. First, acts of antigovernment violence do not necessarily need to be successful, in that they achieve some intended policy outcome in order for actors in a neighboring state to be willing to emulate those actions. Second, actors do not need to seek out all available information concerning events abroad to make rational decisions about whether or not to violently challenge their government.

In explaining the diffusion of pension reform across Latin America, Weyland $(2005,271)$ states, "A bold innovation attracts disproportionate attention from neighboring countries; it is then widely adopted on the basis of its apparent promise, not its demonstrated success...Thus, the cognitive heuristics framework argues that diffusion is shaped by the inferential shortcuts of bounded rationality." We believe two principle inferential shortcuts-availability and representativeness-help explain why actors are likely to emulate acts of anti-government violence occurring in neighboring states.

The availability heuristic is the tendency for people to overemphasize the significance of immediate information, particularly in situations of uncertainty. This tendency is also correlated with the perceived magnitude of the consequences of this information (Kahneman, Slovic and Tversky 1982). In our case, information concerning acts of violence within neighboring states is more likely to be immediately available or present in the minds of those who are informed of the violence. This is especially the case for events that are potentially perceived to be of lesser magnitude, such as nonviolent protests or demonstrations. Though, of course, this does not exclude the potential salience of these types of events in general. Actors will be disproportionately influenced by attention-grabbing events and will be less likely to draw on events perceived to produce consequences of lesser magnitude.

${ }^{2}$ For several prominent examples of rational learning in policy diffusion, see Simmons, Dobbin and Garrett (2006). 
The representativeness heuristic is the tendency to draw excessively confident inferences from observations that may not represent the true population (Kahneman, Slovic and Tversky 1982). In our case, the act of violently challenging one's government may be perceived as an early sign of success in itself, even though it may not achieve the ultimate success of policy change, for example. Actors may then overestimate the probability of success in challenging their own government by generalizing from some immediately available observations of violence in a neighboring country and more readily emulate those actions. These cognitive heuristics then suggest that emulation of anti-government violence in neighboring states will not only occur if those events successfully achieve their end goals. They also suggest that actors do not need to seek out all available information regarding possible choices of behavior in order to rationally resort to emulating the violent actions of their neighbors.

Each of these mechanisms, however, relies on a critical assumption: that individuals are aware that conflict is occurring in a neighboring country. That is, in order for one to emulate the actions of another, one must be informed about those actions. This point is commonly discussed but is often left as an assumption in modeling geographic proximity. For example, Hill and Rothchild (1986) state, "What is transmitted from one country to another is information about the political conflict between one or more collectivities." They argue that observing other groups engaging in political action may stimulate a sense of collective political identity and provide a source of instruction on the means by which to challenge the government, thereby raising the chances of emulating those actions.

In summarizing an argument by Kuran (1998), Maves and Braithwaite (2013, 480) state that, "The declining costs of cross-border communication (in terms of both flows of information and the transportation of goods and peoples) are thus identified as facilitating and increasing tendency toward contagion of civil conflict." Buhaug and Gleditsch (2008) argue that "we expect reference examples and media attention to focus primarily on events in nearby states," suggesting that mechanisms of conflict diffusion depend on information flows to receiving countries creating awareness of violent conflict events abroad.

Although information exposure is clearly recognized as the underlying process that allows emulation to occur, it is simply assumed into the equation using different measures of spatial proximity. In other words, individuals in two contiguous countries should be more informed of the activities occurring in their neighbor's country than those in two non-contiguous countries. This assumes that exposure to information is perfectly correlated with geographical proximity and is then treated as a constant. However, it is potentially unreasonable to make this assumption, since we know that exposure to information varies independently of geographical proximity. If this is true, then the spread of conflict across geographically proximate states should be dependent on the degree to which individuals are informed about neighboring conflicts. Therefore, the degree of information exposure should condition any spatial dependence that exists among acts of anti-government violence across countries.

\section{COMMUNICATION TECHNOLOGY AS A SOURCE OF INFORMATION}

We argue that although two states may share a border, the public within both states, particularly in underdeveloped areas, may be unaware of the events occurring across each other's borders. This may largely be due to the lack of exposure to information. If exposure to information varies across countries, then we cannot assume that contiguity alone is enough to independently explain the cross-border spread of violence. We argue that modern communication technology, such as cell phones and the internet, provides greater and more efficient access to information 
concerning events in neighboring states, thereby allowing the process of emulation to occur and subsequently raising the potential for violence to spread.

In describing the diffusion of protest behavior, Hill, Rothchild and Cameron $(1998,63)$ state, "The spread of tactical knowledge among group members can be facilitated through technological developments that broaden access to political information... mounting mass action that serves as a model for emulation. Improved means for disseminating information also spreads new ideas about mass conflicts to other groups." These groups can exist within and outside of state boundaries.

Communication technology can open up political opportunities previously thought to be unavailable by providing necessary information for collective action against the state or any other entity. Members of the public who traditionally would be unwilling to bear the costs of acting out in opposition for a shared cause no longer face impediments to acquiring information concerning an opposition strategy. In fact, even individuals who may not initially support a cause for violence may begin to support the cause upon acquiring informational cues from the aggregate opposition. Hill, Rothchild and Cameron $(1998,68)$ argue, "Information on political opportunity will spread and promote further conflict within and across groups only when it offers individuals who receive it a reasonable prospect of further net gains." Information acquisition will reduce the cost of collective action, and each additional supporter who is willing to engage in violence increases the likelihood of success, which raises the probability (and the perception) of potentially receiving some net gain.

However, recent evidence of the role of information and communication technology in facilitating violence is far from conclusive in a variety of contexts. In examining the role of the mass media in facilitating violence throughout the Rwandan genocide, Yanagizawa-Drott (2012) finds that pro-government propaganda disseminated through anti-Tutsi radio broadcasts was responsible for coordinating 10 percent of the perpetrators participating in violence. Pierskalla and Hollenbach (2013) find that greater cell phone coverage in Africa significantly increased violent conflict between 2008 and 2010 by allowing opposition groups to more easily overcome collective action problems.

Alternatively, Shapiro and Weidmann (2012) find that the expansion of cellular communications reduced insurgent violence in Iraq at both the district level and specific tower coverage areas. Although the increase in network coverage enhanced insurgent communications, it also increased information flow to counterinsurgent operations, generating a net decrease in insurgent violence. Using a new dataset on cross-national media accessibility, Warren (2014) shows that widespread media access reduces violent challenges to the state when the media disseminates more pro-government propaganda, dissuading potential challenges. Others find a host of outcomes associated with increased communication technology availability, including economic development in India (Abraham 2007), agricultural market efficiency in Niger (Aker 2010), increased voter education and political participation in Mozambique (Aker, Collier and Vincente 2011), and more efficient reporting of violence allowing quicker medical responses (Diamond 2012).

There is no doubt that the proliferation of the internet and cell phones has improved a variety of civil relations throughout Africa. However, if government responsiveness does not improve, and if institutional mechanisms do not evolve to facilitate an internal relationship between the government and the mass public, citizens will simply utilize this technology to change the system in their favor. The efficiency in communications only helps to speed up the process of regime challenge and make it more effective by enabling collective action. If these technologies facilitate the spread of information within countries, and if the mechanism enabling violence to spread across state boundaries is emulation, then increased communications capacities in 
neighboring states should condition the extent to which the neighboring publics emulate the violent actions of their neighbors. We therefore derive the following hypothesis:

HYPOTHESIS 1: Anti-government violence in country $j$ raises the likelihood of anti-government violence in contiguous country $i$ as communications technology increases in country $i$.

\section{DATA AND METHODS}

Our data come from multiple sources. Our outcome variable of anti-government violence is taken from the Social Conflict in Africa Database (SCAD) (Salehyan et al. 2012). ${ }^{3}$ Antigovernment violence is defined in Salehyan et al. (2012) as: "Distinct violent event waged primarily by a non-state group against government authorities or symbols of government authorities (for example, transportation or other infrastructures). As distinguished from riots, the anti-government actor must have a semi-permanent or permanent militant wing or organization." The same distinction between anti-government violence and riots also applies to most of the other outcomes assessed in the SCAD, including demonstrations and strikes which, together with riots, make up the types of political behavior that are most often spontaneously engaged in by segments of the mass population. As it is measured here, anti-government violence applies only to more organized and at least semi-permanent groups that have some level of military capabilities. Nevertheless, the SCAD is generally limited to much lower levels of violence than has previously been examined in a spatial context. We contend that this makes anti-government violence distinct from both protest-oriented events such as demonstrations, riots and strikes as well as higherintensity violent events such as domestic armed conflict and civil war.

The anti-government violence variable in its original form catalogued all acts of antigovernment violence in Africa from 1990-2011. We collapsed this to create a count of anti-government events for each country-year. Further, since we are interested in the effects of newer forms of communication technology (cell phones and the internet) on anti-government violence, we are forced to limit the study to $2000-11$ due to data availability. ${ }^{4}$ Figure 1 shows the number and location of anti-government violent events in Africa over time.

Our theory posits a spatial relationship between the level of anti-government violence in one country and that of a neighbor. As such, we employ a spatial lag that captures this relationship much as a temporal lag captures relationships between outcomes from one year to the next.

\footnotetext{
${ }^{3}$ The SCAD includes data on 49 African countries. We omitted several countries due to a lack of data on our other key variables. We are also limited in our spatial domain due to the data availability of our dependent variable. The only other reputable large-scale data collection efforts on events of lower intensity than domestic armed conflict/civil wars are the Armed Conflict Location and Event Database (ACLED) and the Uppsala Conflict Data Program (UCDP) Georeferenced Event Dataset. ACLED's closest measure to anti-government violence is a measure of "violence against civilians" and only includes nine additional countries outside of Africa. UCDP is also limited to African states, and does not provide a directly comparable measure to antigovernment violence.

4 A measure of radios and various forms of print media exposure would significantly lengthen the temporal range. We intentionally did not use these measures, because they have the highest probability of being controlled by the government. In the majority of countries in our sample, governments heavily influence news coverage through state-run radio broadcasts and printed news sources. The information being spread over internet sources and through person-to-person cell phone communications is far less likely to be manipulated by the state. These mediums of instant communication make it more difficult to monitor. There are cases of governments taking down cell phone towers to prevent communication, but the information that is communicated is not manipulated. We also include a measure of government repression in our models to help control for these potential issues.
} 


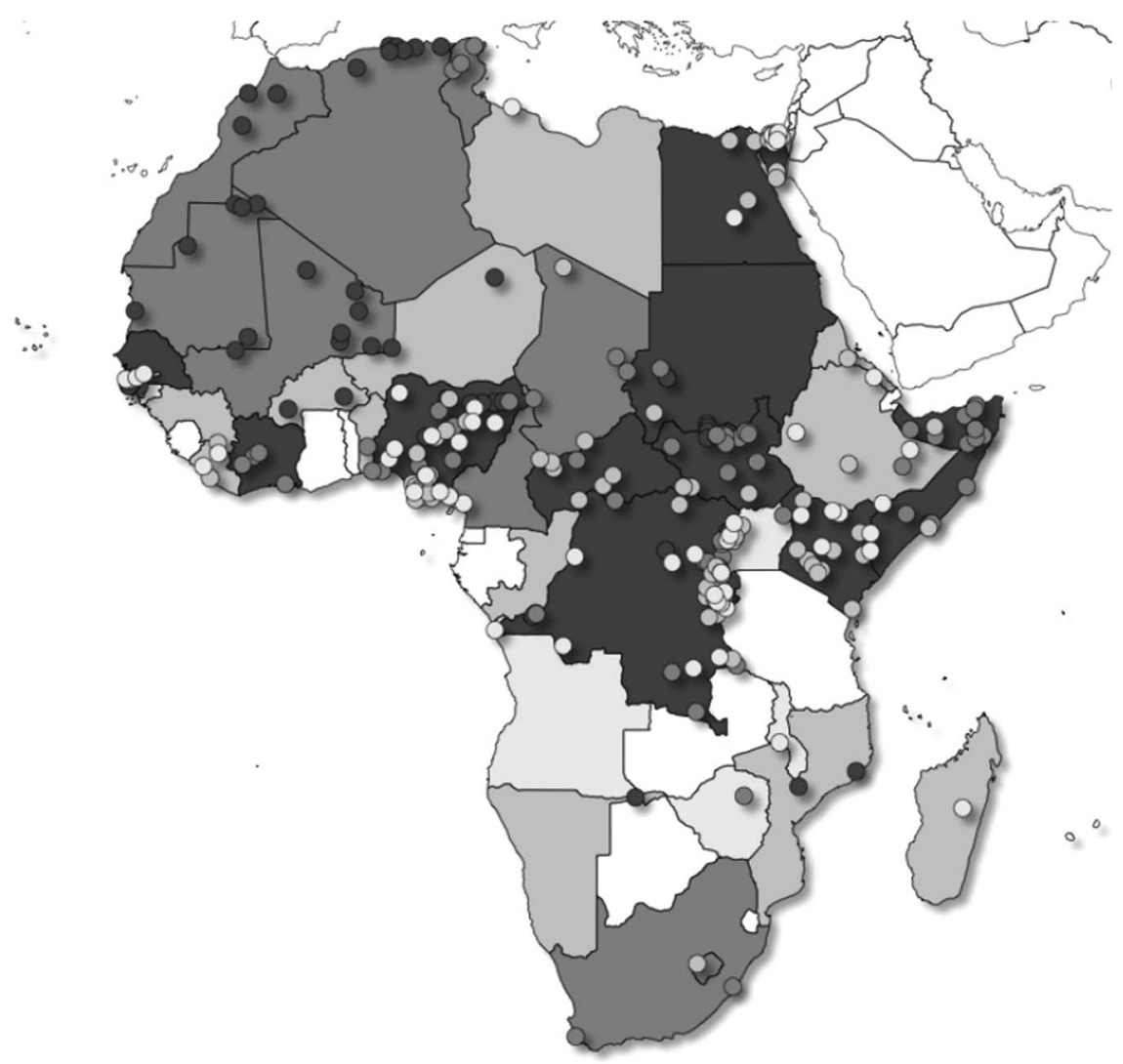

Fig. 1. Anti-government violence in Africa over time (2000-11)

Note: darker shading indicates more events in a given country. Darker dots indicate more events in that exact location. Data are taken from SCAD.

This spatial lag is our primary variable of interest. We further discuss how this variable is operationalized in the next section. Our other primary explanatory variables are the number of cell phone subscribers per capita and the level of internet usage. Both of these measure modern communication technology that is easily accessed by average citizens. This means that individual citizens can rapidly spread information about major events, thus potentially motivating other citizens elsewhere to emulate the action in their own locale. Both connectivity variables are taken from the International Telecommunications Union database. Figure 2 shows the diffusion of cell phone and internet technology in Africa over time.

In order to test the alternative argument that information regarding acts of anti-government violence is spreading by word of mouth from displaced populations rather than through communications technology proliferation, we control for the sum of all refugees from neighboring countries in a given country-year and weight it relative to the size of the host country population. For example, in the case of Nigeria, we sum the total number of refugees coming from only the countries that share a border with Nigeria: Niger, Chad, Cameroon and Benin. Although Nigeria may be receiving refugees from other states, we exclude them in order to better capture the expectation that information about neighboring conflicts is coming directly from migrants who were displaced by those conflicts. Our refugee flow data come from the UN High Commission for Refugees Population Database. 

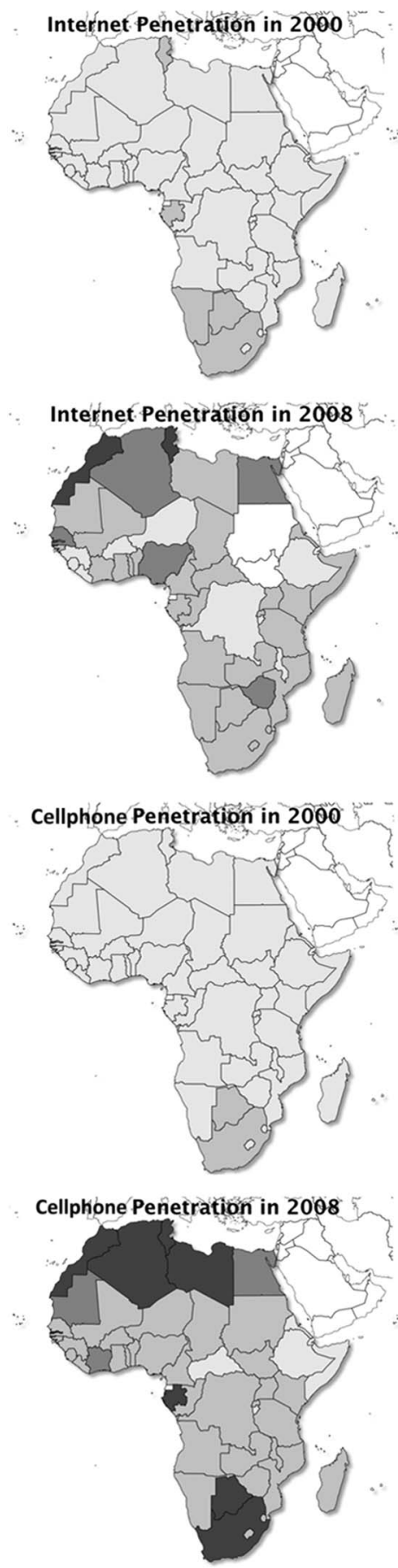

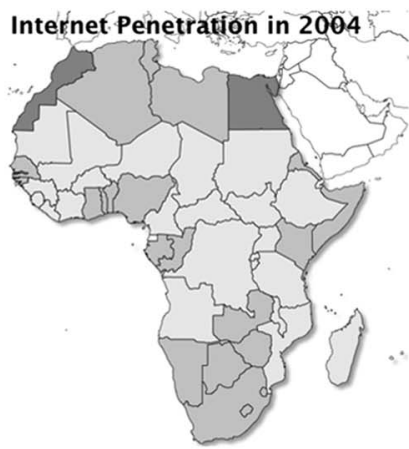

Internet Penetration in 2011

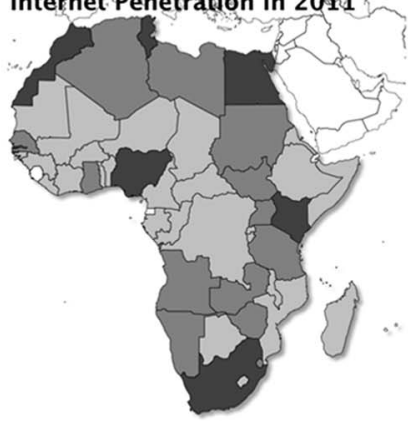

Cellphone Penetration in 2004

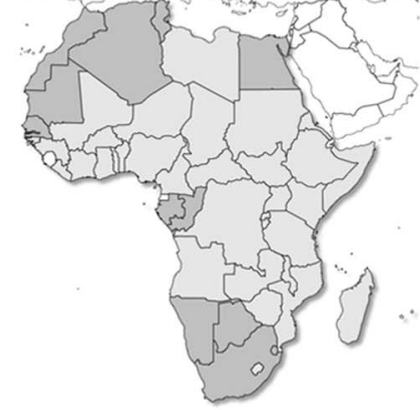

Cellphone Penetration in 2011

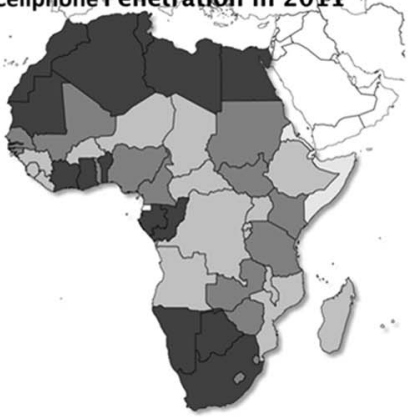

Percentage of people using the internet:

$\square<1$

1-10

$10-20$

$>20$

\section{Cellphone subscribers per 100} people:
$<10$

10-50

50-80

$>80$

Fig. 2. Communication technology diffusion in Africa over time

Note: cell phone and internet data are taken from the International Telecommunications Union website: http:// www.itu.int/en/ITU-D/Statistics/Pages/default.aspxhttp://www.itu.int/en/ITU-D/Statistics/Pages/default.aspx 
We also consider the role played by the government. Recent evidence suggests that elites will likely anticipate the potential for their own citizens to emulate violence abroad. To prevent the potential conflict spillover, the government will pre-emptively repress the public (Danneman and Ritter 2014). Upon observing the use of lethal force by the government, the public might be less likely to engage in anti-government violence in the future. We therefore include a measure of government repression included in the SCAD database. This variable is coded as 1 if one or more acts of anti-government violence were repressed in the previous country-year, and 0 otherwise.

We also include a standard range of control variables typically used in the protest and conflict literatures. We control for the level of democracy by utilizing the Polity IV 10 to -10 standard regime type index as well as the polynomial term (Marshall, Jaggers and Gurr 2012). We do this to test for the common finding that conflict events are more likely to occur in anocratic regimes than in fully fledged democracies or autocracies (Hegre et al. 2001). This measure allows us to determine whether there is an inverted U-shaped curve between democracy and intrastate conflict.

We control for the level of urbanization using a measure of the percentage of people living in urban areas. We expect that more urban areas increase communication connectivity and thus increase the potential for violence emulation. Ethnic heterogeneity is an important consideration in Africa (Horowitz 1985; Hill and Rothchild 1986; Collier and Hoeffer 2002; Posner 2004). To account for this, we employ the (Alesina et al. 2003) measure of ethno-linguistic fractionalization. We also include a measure of repression of events in the SCAD database. This is coded as a dummy variable representing government repression for an event in the previous year. Finally, we also include the standard controls of GDP per capita and population, since higher average incomes would likely facilitate and provide the opportunity and capacity to plan, organize and execute successful events. Likewise, countries with larger populations tend to generate higher policing costs and have been found to be strongly associated with violent events (Eyerman 1998). Table 1 lists all variables used in our analyses along with our expected relationships, coding, sources and summary statistics.

\section{Modeling Spatial Dependence and Communications Technology Connectivity}

Models of spatial dependence are becoming increasingly prevalent in social science research, including the conflict and violence literatures. However, much of this research has employed relatively basic treatments of spatial connectivity. Beyond simply accounting for residual spatial effects to get unbiased coefficients, researchers can theorize and predict the impact of spatial dependence on the outcome of interest. Franzese and Hays (2008a, 2008b) argue that spatial dependence is more than a nuisance or control; rather, it is substantive. We also take this approach and choose to model the spatial dependence, instead of just accounting for it.

Much attention in the spatial econometric literature is necessarily given to the so-called spatial weights (or W) matrix (Plümper and Neumayer 2010; Neumayer and Plümper 2014). This matrix provides the information on connectivity from one unit to another $\left(j\right.$ to $i$ in matrix element $w_{i j}$ ) that allows the researcher to model spatial dependence. As such, determining the proper mode of connectivity and constructing the weights matrix is far from trivial. Indeed, the information used to determine the interconnectivity of units can seriously condition the results of any analyses (see Neumayer and Plümper in this issue). The specification of the weights matrix is perhaps the most important consideration when constructing models and theories of spatial dependence.

We began our analyses with a simple neighbor connectivity matrix, $\mathbf{W}_{i j}$, where a country takes a value of 1 when it shares a border with another and 0 when it does not. Much of the spatial literature stops at this matrix, thus assuming that spatial dependence is primarily driven by geography (Beck, Gleditsch and Beardsley 2006). We start with this type of weights matrix 
TAB LE $1 \quad$ Variables, Coding, Expected Relationships and Sources

\begin{tabular}{|c|c|c|}
\hline Variable and Summary Statistics & Expectation & Coding / source \\
\hline $\begin{array}{l}\text { Anti-Government Violence: } \mu=0.72, \sigma=2.55 \text {, } \\
\quad \text { range }=0-38, N=528\end{array}$ & Outcome variable & Number of events per country-year (SCAD). \\
\hline $\begin{array}{l}\text { Spatial Lag: } \mu=1.38, \sigma=1.63 \text {, range }=0-9.96 \\
\quad N=528\end{array}$ & $\begin{array}{l}+ \text { Increased spatial dependence leads to more } \\
\text { violence in country } j\end{array}$ & $\ln \left(y_{t}+1\right) * w_{i j}\left(\operatorname{SCAD} \& W_{i j}\right.$ matrix $)$ \\
\hline $\begin{array}{l}\text { Cell phone users: } \mu=25.41, \sigma=30.56 \\
\text { range }=0-171.52, N=524\end{array}$ & $\begin{array}{l}+ \text { More cell phone subscriptions leads to more } \\
\text { violence in country } j\end{array}$ & Number of cell subscriptions per 100 people (ITU) \\
\hline $\begin{array}{l}\text { Internet: } \mu=4.25, \sigma=6.72 \text {, range }=0.01-51 \text {, } \\
\quad N=521\end{array}$ & $\begin{array}{l}+ \text { Higher internet usage leads to more violence in } \\
\text { country } j\end{array}$ & Percent of population using the internet (ITU) \\
\hline $\begin{array}{l}\text { Repression: } \mu=0.69, \sigma=0.464 \text {, range }=0-1 \text {, } \\
\quad N=484\end{array}$ & $\begin{array}{l}\text { - Repression in previous year leads to less anti- } \\
\text { government violence }\end{array}$ & $\begin{array}{l}1=\text { government repression of SCAD event in previous } \\
\text { year; } 0=\text { No repression }\end{array}$ \\
\hline $\begin{array}{l}\text { Refugees: } \mu=0.004, \sigma=0.007, \text { range }=0-0.05 \\
\quad N=528\end{array}$ & $\begin{array}{l}+ \text { More refugees leads to more anti-government } \\
\text { violence }\end{array}$ & $\%$ pop refugees from neighboring countries (UNHCR) \\
\hline Polity: $\mu=0.82, \sigma=5.10$, range $=-9-9, N=527$ & - More democratic leads to less violence & Combined scale: -10 to 10 (Polity IV) \\
\hline $\begin{array}{l}\ln (G D P \text { per capita }): \mu=6.57, \sigma=1.09 \\
\text { range }=4.52-9.671, N=526\end{array}$ & - Higher GDP per capita leads to less violence & Natural log of GDP (WB) \\
\hline $\begin{array}{l}\ln (\text { Population }): \mu=16.14, \sigma=1.19 \\
\quad \text { range }=13.83-18.91, N=528\end{array}$ & $\begin{array}{l}+ \text { Higher population densities lead to more } \\
\text { violence }\end{array}$ & Natural log of total population (WB) \\
\hline $\begin{array}{l}\text { Ethnic Fractionalization: } \mu=0.66, \sigma=0.23 \text {, } \\
\text { range }=0.04-0.93, N=528\end{array}$ & + More heterogeneity leads to more violence & Herfindahl index: $F R A C T_{j}=1 \sum_{i=1} s_{i j}^{2}$. (Alesina et al. 2003) \\
\hline $\begin{array}{l}\text { Election in Same Year: } \mu=0.22, \sigma=0.41 \\
\quad \text { range }=0,1, N=528\end{array}$ & $\begin{array}{l}+ \text { An election in the same year leads to more } \\
\text { violence }\end{array}$ & 1 = Election; 0 = No election (IDEA) \\
\hline $\begin{array}{l}\text { Urbanization: } \mu=38.41, \sigma=17.50 \\
\quad \text { range }=8.25-86.15, N=528\end{array}$ & $\begin{array}{l}+ \text { More urbanization facilitates more potential } \\
\text { violence }\end{array}$ & $\%$ Urbanized (WB) \\
\hline
\end{tabular}

Note: SCAD: Social Conflict in Africa Database; ITU: International Telecommunications Union; IDEA: Institute for Democratic and Electoral Assistance; WB: World Bank; UNHCR: United Nations High Commission for Refugees. 
because of the unique nature of the African geopolitical system. Alternative specifications to this are distance-based matrices or a matrix based on some other spatial connectivity besides physical contiguity. We have considered both options. A distance-based matrix based on some arbitrary point, or administrate capital, is problematic in Africa because of the large variance in administrative area and capital placement. On the one hand, making the distances too short would underestimate the connectivity of countries such as Sudan, Libya and Egypt, all of which had significant numbers of social conflicts during the Arab Spring, for example. On the other hand, a larger distance would overestimate the connectivity of the smaller Western African countries, with many non-neighbors being possibly erroneously connected.

From our proposed theoretical framework, an ideal weights matrix would be based on the connectivity of communication technology between countries, but such information is not currently available. Nevertheless, we go beyond a simple geographic adjacency matrix by interacting our primary explanatory variables of internet usage and cell phone subscribers with the spatial lag. This creates a new variable that includes information on both geographic connectivity and the channels of information flow that we focus on in this article. We posit that this treatment of spatial connectivity is an important contribution for two reasons. First, we are attempting to model our theorized channel of connectivity, in this case the flow of information. Second, in the absence of a global connectivity communication technology matrix, this interactive spatial lag represents a significant improvement over a typical adjacency matrix. Our matrix is not row-standardized, as we have no theoretical justification for doing so. ${ }^{5}$

Our theoretical focus is on how information can lead to emulation through technology. Specifically, we theorize about how this information is spread from one unit to the other ( $i$ to $j$ ), and perhaps more importantly, the mechanisms through which this diffusion takes place. Much of the spatial literature leaves this particular area of spatial diffusion unexplored. Knowing that diffusion is happening may not be enough. Further, simply knowing or theorizing that $y_{i}$ affects $y_{j}$, while more useful than the alternative of assuming no spatial dependence, may also fall short of telling the whole story. We posit that the method of diffusion may condition the impact of the spatial effects. ${ }^{6}$ We model our theory by conditioning the connectivity matrix with our primary explanatory variables.

\footnotetext{
${ }^{5}$ In this case, row-standardizing did not significantly bias the results, although it can often produce distinct results from a non-standardized matrix (Plümper and Neumayer 2010).

${ }^{6}$ One could also argue that the severity of an act of anti-government violence could increase the likelihood of emulation, since news of these events would be more likely to spread than less severe events. However, our conceptual framework based on the use of cognitive heuristics would argue that this link is based on a reference point. For example, if a single event occurs that kills ten people, there will be a high degree of variation in perceptions of the event being "severe," "moderately severe" or a minor event. In this case there is no reference point that we can draw upon to classify the severity of the event. However, if an event occurred one year prior that killed 200 people, then we would have a point of reference telling us that the current event is less severe. Therefore, what might be considered a "less severe" event (if there were more severe events from which to draw a point of reference) would likely produce an equal amount of coverage as a "more severe" event in the absence of other more severe events in the unit of analysis. Less severe events should thus, on average, produce an equal likelihood of emulation as more severe events if these events occur at different points in time. Although there are a fair number of country-years in our sample that only experience one act of anti-government violence, a significantly larger proportion experiences more than one event. In this case, less severe attacks occurring simultaneously with more severe attacks will likely lead to greater coverage because of the combined perception of the attacks, leading to a greater likelihood of emulation. We capture this aspect in our models since we are multiplying the number of events in country $i$ (the neighboring country) by the level of communications technology in country $j$. In fact, the spatial matrix allows us to incorporate the average (and then weighted or unweighted) number of events of all neighboring countries $i$ on the likelihood of an event in country $j$, which is what we have reported in our models.
} 


\section{Model Specification}

Since our outcome variable is a count, we follow the standard approach of using negativebinomial estimation. We chose negative-binomial over poisson because of the over-dispersion of the dependent variable (Long 1997; Hilbe 2011). We also follow Neumayer and Plümper (2010) by taking the advice of Hays and Franzese (2009), who suggest that $\mathbf{W}[\ln (y+1)]$ provides a better proxy of the actual event counts opposed to Wy. We clustered the standard errors around country.

Finally, we also consider the trend and shock effects of time in our analyses. We deal with common shocks by including time fixed effects for each year. For trends, we include a timelagged (one year) dependent variable. Both of these approaches are common procedures for dealing with time-related issues in the recent spatial econometrics literature (Beck, Gleditsch and Beardsley 2006; Franzese and Hays 2007; Neumayer and Plümper 2010, 2011; Plümper and Neumayer 2010). Failure to control for these time effects could overestimate the spatial dependence we are interested in modeling (Plümper and Neumayer 2010). Finally, the inclusion of a lagged dependent variable also makes theoretical sense in that there is likely an autoregressive nature to these events in given countries, whether spatial dependence is present or not. We specify our full model as:

$$
y_{i t}=\rho \mathbf{W} y_{i t}+z_{i t} \gamma+\psi \mathbf{W} y_{i t} z_{i t}+\phi y_{t 1}+\mathbf{x}_{i t}^{\prime} \beta+\delta_{t}+\varepsilon_{i t},
$$

where:

- $y_{i t}$ is the number of violent anti-government events in country $i$ in year $t$.

- $\mathbf{W} y_{i t}$ is the spatial lag, with $\mathbf{W}$ being a matrix of connectivity containing elements $w_{i j}$ with parameter estimate $\rho$.

- $z_{i t}$ is the level of communication technology (cell phone or internet) for each country-year with parameter estimate $\gamma$.

- $\mathbf{W} y_{i t} z_{i t}$ is the interaction of communication technology and the spatial lag with parameter estimate $\psi$.

- $y_{t-1}$ is a one-year (first-order) lag of anti-government violent events with temporal autoregressive parameter estimate $\phi$.

- $\mathbf{x}_{\mathbf{i t}}^{\prime}$ is a vector of observations on our control variables with parameter estimates vector $\beta$.

- $\delta$ is a vector of time (year) fixed effects.

- $\varepsilon_{i t}$ is the disturbance term.

\section{RESULTS AND DISCUSSION}

Table 2 presents the negative binomial estimation results. The first model includes the number of cell phone subscribers per 100 people, while the second model includes the percentage of the population using the internet. Each of these is interacted with the spatial lag to create our primary variable of interest. In both cases, the estimate on the interaction terms is positive and significant, thus lending support to our expectation that anti-government violence in country $j$ increases the likelihood of violence in $i$ under increasing levels of communication technology in country $i{ }^{7}$ The time-lagged dependent variable is also positive and significant, indicating that

\footnotetext{
${ }^{7}$ As an additional robustness check, we test our argument on the other outcomes in the SCAD database including demonstrations, riots and strikes, as well as terror attacks targeting government infrastructure, the military and police, taken from the Global Terrorism Database. We find no significant positive relationship with these outcomes. Estimation results are provided in the online appendix.
} 
TABLE 2 The Spatial Dependence of Anti-Government Violence

\begin{tabular}{|c|c|c|}
\hline Predictor & Cell Phone Use & Internet \\
\hline Spatial Lag & $\begin{array}{c}-0.155 \\
(0.119)\end{array}$ & $\begin{array}{l}-0.068 \\
(0.090)\end{array}$ \\
\hline Cell & $\begin{array}{r}-0.009 \\
(0.009)\end{array}$ & \\
\hline Internet & & $\begin{array}{l}-0.005 \\
(0.022)\end{array}$ \\
\hline Spatial Lag $\times$ Cell & $\begin{array}{l}0.006 * * \\
(0.003)\end{array}$ & \\
\hline Spatial Lag $\times$ Internet & & $\begin{array}{l}0.016 * * * \\
(0.006)\end{array}$ \\
\hline $\mathrm{AGV}_{t-1}$ & $\begin{array}{l}1.119 \text { *** } \\
(0.138)\end{array}$ & $\begin{array}{l}1.091 * * * \\
(0.135)\end{array}$ \\
\hline Repression $_{t-1}$ & $\begin{array}{c}0.380 \\
(0.295)\end{array}$ & $\begin{array}{c}0.358 \\
(0.311)\end{array}$ \\
\hline Refugees & $\begin{array}{c}9.095 \\
(15.084)\end{array}$ & $\begin{array}{c}8.017 \\
(15.835)\end{array}$ \\
\hline Polity & $\begin{array}{c}-0.002 \\
(0.027)\end{array}$ & $\begin{array}{c}0.000 \\
(0.032)\end{array}$ \\
\hline Polity $^{2}$ & $\begin{array}{c}0.001 \\
(0.005)\end{array}$ & $\begin{array}{c}0.002 \\
(0.005)\end{array}$ \\
\hline $\ln ($ GDP per capita) & $\begin{array}{r}-0.059 \\
(0.210)\end{array}$ & $\begin{array}{r}-0.242 \\
(0.160)\end{array}$ \\
\hline $\ln$ (Population) & $\begin{array}{l}0.351 * * * \\
(0.126)\end{array}$ & $\begin{array}{l}0.301 * * \\
(0.146)\end{array}$ \\
\hline Ethnic Fractionalization & $\begin{array}{c}0.276 \\
(0.476)\end{array}$ & $\begin{array}{c}0.330 \\
(0.480)\end{array}$ \\
\hline Election in Same Year & $\begin{array}{c}0.261 \\
(0.200)\end{array}$ & $\begin{array}{c}0.141 \\
(0.218)\end{array}$ \\
\hline Urbanization & $\begin{array}{c}0.001 \\
(0.011)\end{array}$ & $\begin{array}{c}0.007 \\
(0.010)\end{array}$ \\
\hline Constant & $\begin{array}{c}-8.402 * * * \\
(2.036)\end{array}$ & $\begin{array}{c}-6.742 * * * \\
(2.460)\end{array}$ \\
\hline $\begin{array}{l}\text { Wald } \chi^{2} \\
\text { Log Pseudolikelihood } \\
N\end{array}$ & $\begin{array}{c}2154.29 * * * \\
-378.122 \\
477\end{array}$ & $\begin{array}{c}1463.34 * * * \\
-369.285 \\
474\end{array}$ \\
\hline
\end{tabular}

Note: negative binomial estimation results. The outcome variable in both models is the number of antigovernment violence $(\mathrm{AGV})$ events. Clustered standard errors are in parentheses. Yearly time dummies were included in estimation but are not shown. ***p $<0.01 ; * * p<0.05 ; * p<0.10$.

there is an autoregressive nature to anti-government violence in these countries during the 2000-11 time period.

Although there is strong evidence in the literature that governments often engage in pre-emptive repression upon observing conflicts in neighboring countries in order to deter emulation behavior, we find no evidence that government repression inhibits the emulation of anti-government violence in our context. It also appears that the flow of refugees does not play a role in the diffusion of information leading to the emulation of anti-government violence. Although several studies show that the flow of refugees is a significant predictor of the cross-border spread of civil war (Salehyan and Gleditsch 2006; Buhaug and Gleditsch 2008), our insignificant finding aligns with our expectation that acts of anti-government violence will not produce large enough displaced populations to serve as the predominant diffusion mechanism. Instead, our findings provide evidence that the emulation of anti-government violence results from information about neighboring violence received through communications technology. 
Population was the only control variable to achieve statistical significance; higher populations were associated with more violent anti-government events in both models. These results generally hold across different specifications and modeling techniques. We tested these models with measures of technology from other sources, and the substantive interpretation did not change. Further, using non-clustered standard errors or row-standardizing the weights matrix had little overall impact. Finally, the dispersion parameterization (constant or mean) had no impact on our findings. All of this indicates that our models are robust to alternative specifications and gives us more confidence in the results. ${ }^{8}$

\section{Substantive Effects}

Although examining the direction and conventional statistical significance levels of the model coefficients is informative, the negative binomial specification does not provide a strong sense of the substantive impact or of the magnitude of the effects on anti-government violence. Because this is of particular interest when interpreting our interaction effects, we also investigate the degree to which anti-government violence becomes spatially dependent across more meaningful scenarios of the modifying variables by calculating adjusted predicted counts of the spatial lag on anti-government violence as well as the percentage increase in the estimated number of events in the following country-year.

In Figure 3 we present the predicted counts of the spatial lag on anti-government violence as the percentage of cell phone subscribers and internet usage changes. In each case, the graphs indicate that the most significant moderating effects take place toward the middle of the distributions of cell phones and internet access. If the graphs were extended to include out-of-sample predictions, we would expect to see an increasing impact on the predicted number of events as cell phone and internet penetration increase, although the confidence intervals are trending toward insignificance. This potentially indicates that at some point higher levels of communications technology become associated with higher levels of economic development and democratic consolidation, which are conditions in which we would expect to see less anti-government violence.

Given the difficulty of interpreting interactions in which both variables are continuous, we now turn to a series of scenarios in which we employ incident rate ratios. In Table 3 we present the effect that a one-standard-deviation increase in the spatial lag has on anti-government violence in country $i$, given eight meaningful changes in the modifying variables while controlling for the additional explanatory factors presented in our models. ${ }^{9}$ Figure 3 displays the adjusted predicted counts of anti-government violence under different scenarios for our interactions. In the case of the incident rate ratios, we are presenting percentage changes in the likelihood that an event will occur.

We began by estimating the effect of a positive standard-deviation change in the spatial lag on the percentage of violent events under the extreme case that there are no cell phone subscribers in a given country-year. This allows us to observe the effect of increasing spatial dependence on anti-government violence, solely determined by geographical proximity. When there are no cell phone subscribers, we expect there to be no relationship between our spatial lag and violent events. This condition produced 2.20 percent fewer violent events, however the relationship is insignificant, as expected. ${ }^{10}$ When the number of cell phone subscribers moves

\footnotetext{
${ }^{8}$ Any of these alternative specifications will be available in the online appendix.

9 This technique provides a more meaningful way of interpreting continuous $x$ continuous interaction terms in the negative binomial context, and is suggested by Hilbe $(2011,528)$.

${ }^{10}$ Only five observations (or roughly 0.011 percent of country-years) had zero cell phone subscribers. These include Guinea-Bissau from 2001 to 2002 and Eritrea from 2001 to 2003.
} 


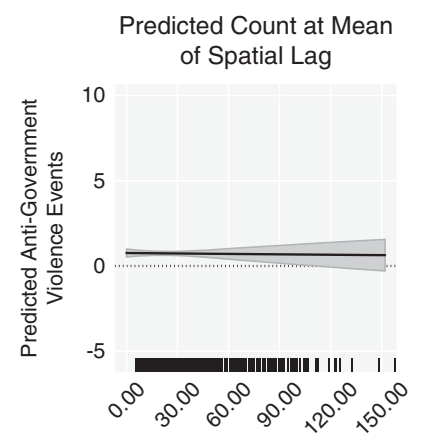

Number of Cellphone Subscribers per 100 People

Predicted Count at Mean of Spatial Lag

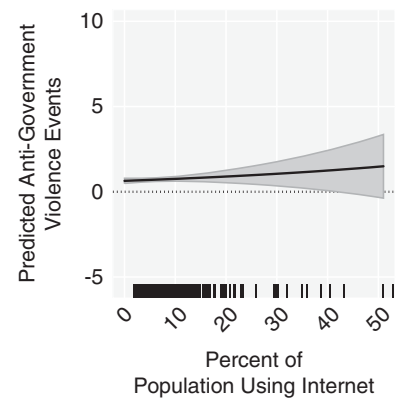

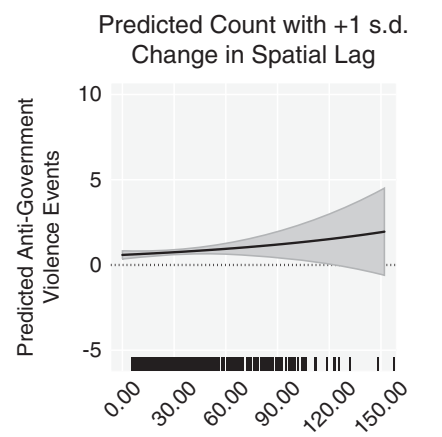

Number of Cellphone Subscribers per 100 People

Predicted Count with +1 s.d. Change in Spatial Lag

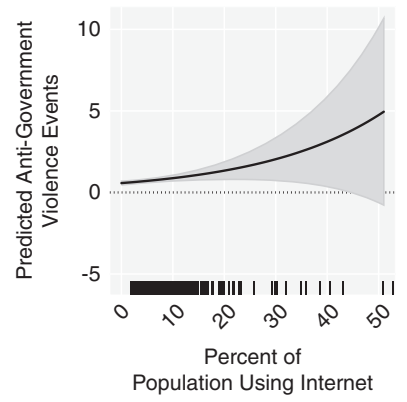

Predicted Count with +2 s.d. Change in Spatial Lag

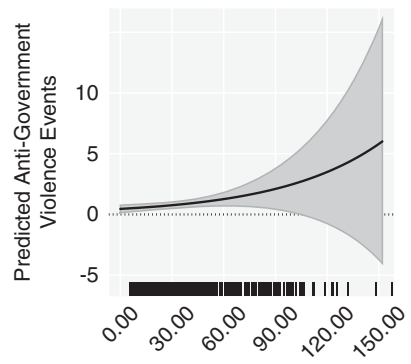

Number of Cellphone Subscribers per 100 People

Predicted Count with +2 s.d. Change in Spatial Lag

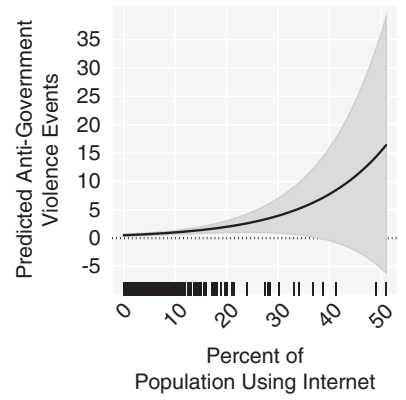

Fig 3. Predicted counts of anti-government violence

Note: each graph is the adjusted predicted count of violent anti-government events under a meaningful scenario for the spatial lag being moderated by communications technology. These graphs were generated using the marginsplot function in Stata 12/13. Please see our reproduction files for more information.

from zero to five out of 100 people, there is a 4.6 percent increase in the expected number of violent events. ${ }^{11}$ A move from five to ten subscribers results in a 9.5 percent increase in the expected number of violent events. ${ }^{12}$ Finally, moving from the mean number of cell phone subscribers to one standard deviation above the mean (27 to 57) produced about a 32 percent increase in the expected number of violent events.

We then estimated the effects under meaningful values of internet users. Again, we chose to first examine the extreme case of there being no internet users in a given country-year, producing 0.01 percent fewer violent events, which again is insignificant, as expected. Although our sample includes no country-years in which there are zero internet users, 233 (about 50 percent) of our observations have only 2 percent of the population or fewer internet users in a given countryyear. Moving from less than 1 percent to 2 percent of the population using the internet generated a 5.3 percent increase in the expected number of violent events. Moving from just 2 to 5 percent internet users produced a 13.7 percent increase in the expected number of violent events. Finally, moving from the mean percentage of internet users in a country-year to one standard deviation above the mean (4.49 percent to 11.23 percent), representing 90 observations or 19.25 percent of the sample, increased the expected number of violent events by 18.9 percent.

\footnotetext{
11 This represents 145 in-sample observations (or roughly 31 percent of the sample).

12 This represents 52 observations ( 11 percent of the sample).
} 
TABLE 3 Substantive Impact on Anti-Government Violence

\begin{tabular}{lllll}
\hline $\begin{array}{l}\text { Unit Change in Spatial } \\
\text { Lag }\end{array}$ & $\begin{array}{l}\text { Movement in Modifying } \\
\text { Variable }\end{array}$ & $\begin{array}{l}\text { Effect on } \\
\text { AGV }\end{array}$ & IRR & $\begin{array}{l}\text { 90\% Confidence } \\
\text { Intervals }\end{array}$ \\
\hline \multirow{3}{*}{$+1 \mathrm{SD}$} & Cell Subscribers & & & \\
& $=0 \%$ & $-2.2 \%$ & .978 & {$[0.792,1.207]$} \\
& $0 \rightarrow 5 \%$ & $+4.6 \%$ & 1.046 & {$[1.009,1.085]$} \\
& $5 \rightarrow 10 \%$ & $+9.5 \%$ & 1.095 & {$[1.019,1.177]$} \\
& $\bar{x} \rightarrow+1 \mathrm{SD}$ & $+32.0 \%$ & 1.319 & {$[1.059,1.644]$} \\
& & & & \\
& Internet Usage & & & \\
& $=0 \%$ & $-0.01 \%$ & 0.999 & {$[0.814,1.226]$} \\
& $<1 \rightarrow 2 \%$ & $+5.3 \%$ & 1.053 & {$[1.022,1.085]$} \\
& $2 \rightarrow 5 \%$ & $+13.7 \%$ & 1.137 & {$[1.055,1.225]$} \\
& $\bar{x} \rightarrow+1 \mathrm{SD}$ & $+18.9 \%$ & 1.189 & {$[1.075,1.314]$} \\
\hline
\end{tabular}

Note: the percentage impacts are the exponentiated coefficients (incident rate ratios) of the negative binomial estimations with centered interaction terms.

These substantive impacts serve as a strong validation of our theoretical expectations and clearly illustrate the importance of directly modeling the flow of information in this context. Anti-government violence can spread to a great extent across state boundaries, but contiguity alone is not necessarily responsible for this spread. Actors emulate these violent events against their own government only after observing or being informed of similar events in neighboring states. This flow of information, represented here through cell phone subscriptions per 100 people and the percentage of internet users, strongly condition the degree to which violence is spatially dependent across states.

\section{CONCLUSION}

In this article we examined whether acts of anti-government violence exhibit spatial dependence across state boundaries. In line with previous work, we argued that the mechanism allowing violence to spread was action emulation. In other words, actors in one country observe violent events occurring in their neighbor and emulate those actions against their own government. However, previous analyses measure spatial dependence purely through a geographical contiguity matrix, which theoretically assumes that all actors are equally aware of the violent events occurring in their neighboring state. Because access to information varies across countries, we argued that the degree to which anti-government violence is spatially dependent should be conditioned by the proliferation of information concerning neighboring events. Our analyses confirmed this expectation. Acts of anti-government violence are only likely to spread across state boundaries when access to information is high.

Our theoretical contributions are relevant to both the general spatial and conflict literatures. Theorizing the mode of connectivity, in this case information, allowed for a more properly specified test than simply assuming that connectivity existed based solely on geographic contiguity. We used a unique approach to modeling spatial dependence by interacting our spatial lag with our main explanatory variable, which allowed us to capture the conditional effects of contiguity. We also moved beyond examining traditional domestic armed conflicts and civil wars by analyzing anti-government event counts. Because these events are the least likely form of domestic opposition to produce displaced populations and refugees, they are also least likely to produce the spread of information across borders through word of mouth. 
Future research should attempt to identify connectivity mechanisms beyond geographical adjacency. This would allow us to examine communication technology usage in both units $j$ and $i$. This, of course, requires much more comprehensive data than are currently available. In the meantime, we have offered a method to analyze spatial dependence beyond pure geographic connectivity. Interacting a properly specified adjacency matrix with a conditioning variable allows for an analysis based more on theoretical information than geography. We can also imagine cases beyond conflict and violence in which access to information can facilitate emulation across spatial boundaries. For example, less severe forms of protest and political behavior could easily fall into this category. Finally, there are almost unlimited instances beyond geographic contiguity that would provide more appropriate tests of theories concerning diffusion processes and violent outcomes. For example, countries with similar institutional characteristics that are associated with proneness to violence might experience similar patterns of violence. This could be easily modeled in a spatial weights matrix that measures whether or not groups of countries share specific institutional qualities. We could then predict specific spatial patterns of violence based on those defined spatial assignments. We believe this study furthers our understanding of the spatial influences in violence.

\section{REFERENCES}

Abraham, Reuben. 2007. 'Mobile Phones and Economic Development: Evidence from the Fishing Industry in India'. Information Technologies and Economic Development 4(1):5-17.

Aker, Jenny C., Paul Collier, and Pedro C. Vincente. 2011. 'Is Information Power? Using Cell Phones During an Election in Mozambique'. Center for Global Development. Working Paper 328.

Aker, Jenny C. 2010. 'Information from Markets Near and Far: Mobile Phones and Agricultural Markets in Niger'. American Economic Journal: Applied Economics 2:46-59.

Alesina, Alberto, Arnaud Devleeschauwer, William Easterly, Sergio Kurlat, and Romain Wacziarg. 2003. 'Fractionalization'. Journal of Economic Growth 8(2):155-94.

Anselin, Luc, and John O'Loughlin. 1992. 'Geography of International Conflict and Cooperation: Spatial Dependence and Regional Context in Africa'. In The New Geopolitics, edited by Michael D. Ward. Gordon and Breach, 39-75. Philadelpia, PA: Science Publishers.

Beck, Nathaniel, Kristian Skrede Gleditsch, and Kyle Beardsley. 2006. 'Space is More Than Geography: Using Spatial Econometrics in the Study of Political Economy'. International Studies Quarterly 50(1):27-44.

Braithwaite, Alex. 2006. 'The Geographic Spread of Militarized Disputes'. Journal of Peace Research 43(5):507-22.

— 2010. 'Resisting Infection: How State Capacity Conditions Conflict Contagion'. Journal of Peace Research 47(3):311-19.

Braithwaite, Alex, and Quan Li. 2007. 'Transnational Terrorism Hotspots: Identification and Impact Evaluation'. Conflict Management and Peace Science 24(4):281-96.

Buhaug, Halvard, and Kristian Skrede Gleditsch. 2008. 'Contagion or Confusion? Why Conflicts Cluster in Space'. International Studies Quarterly 52(2):215-33.

Cliff, Christina, and Andrew First. 2013. 'Testing for Contagion/Diffusion of Terrorism in State Dyads'. Studies in Conflict \& Terrorism 36(4):292-314.

Collier, Paul, and Anke Hoeffler. 2002. 'On the Incidence of Civil War in Africa'. Journal of Conflict Resolution 46(1):13-28.

Danneman, Nathan, and Emily Ritter. 2014. 'Contagious Rebellion and Preemptive Repression'. Journal of Conflict Resolution 58(2):254-79.

Diamond, Larry. 2012. 'Liberation Technology'. In Liberation Technology: Social Media and the Struggle for Democracy, edited by Larry Diamond and Marc F. Plattner, 3-17. Baltimore, MD: Johns Hopkins University Press. 
Elkins, Zachary, and Beth Simmons. 2005. 'On Waves, Clusters, and Diffusion: A Conceptual Framework'. Annals of the American Academy of Political and Social Science 598:33-51.

Eyerman, Joe. 1998. 'Terrorism and Democratic States: Soft Targets or Accessible Systems'. International Interactions 24(2):151-70.

Franzese, Robert J., Jr., and Jude C. Hays. 2007. 'Spatial Econometric Models of Cross-Sectional Interdependence in Political Science Panel and Time-Series-Cross-Section Data'. Political Analysis 15(2):140-64.

2008a. 'Empirical Models of Spatial Interdependence'. In Oxford Handbook of Political Methodology, In Oxford Handbook of Political Methodology. edited by J. Box-Steffensmeier, H. Brady, and D. Collier, 570-604. Oxford: Oxford University Press.

- 2008b. 'Interdependence in Comparative Politics'. Comparative Political Studies 41(4-5):742-80.

Galton, Francis. 1889. 'Discussion on Edward B. Tylor's On a Method of Investigating the Development of Institutions, Applied to Laws of Marriage and Descent'. Journal of the Anthropological Institute of Great Britain and Ireland 18:270-72.

Gleditsch, Kristian Skrede. 2002. All International Politics is Local: The Diffusion of Conflict, Integration, and Democratization. Ann Arbor: University of Michigan Press.

2007. 'Transnational Dimensions in Civil War'. Journal of Peace Research 44(3):293-309.

Govea, R., and G. West. 1981. 'Riot Contagion in Latin America, 1949-1963'. Journal of Conflict Resolution 25(2):349-68.

Gurr, Ted Robert. 1993. 'Why Minorities Rebel: A Global Analysis of Communal Mobilization and Conflict since 1945'. International Political Science Review 14(2):161-201.

Hays, Jude C., and Robert J. Franzese. 2009. 'A Comparison of the Small-Sample Properties of Several Estimators for Spatial-Lag Count Models'. Working Paper.

Hegre, Håvard, Tanja Ellingsen, Scott Gates, and Nils Petter Gleditsch. 2001. 'Toward a Democratic Civil Peace? Democracy, Political Change, and Civil War, 1816-1992'. American Political Science Review 95(1):33-48.

Hilbe, Joseph M. 2011. Negative Binomial Regression. Cambridge: Cambridge University Press.

Hill, Stuart, and Donald Rothchild. 1986. 'The Contagion of Political Conflict in Africa and the World'. Journal of Conflict Resolution 30(4):716-35.

Hill, Stuart, Donald S. Rothchild, and Colin Cameron. 1998. 'Tactical Information and the Diffusion of Peaceful Protests'. In The International Spread of Ethnic Conflict: Fear, Diffusion, Escalation, edited by David A. Lake and Donald S. Rothchild, 61-88. Princeton, NJ: Princeton University Press.

Horowitz, Donald L. 1985. Ethnic Groups in Conflict. Berkeley: University of California Press.

Kahneman, Daniel, Paul Slovic, and Amos Tversky. 1982. Judgment Under Uncertainty: Heuristics and Biases. Cambridge: Cambridge University Press.

Kuran, Timur. 1998. 'Ethnic Dissimilation and its International Diffusion'. In The International Spread of Ethnic Conflict: Fear, Diffusion, Escalation, edited by David A. Lake and Donald S. Rothchild, 35-60. Princeton, NJ: Princeton University Press.

Lake, David A., and Donald S. Rothchild, eds. 1998. The International Spread of Ethnic Conflict: Fear, Diffusion, Escalation. Princeton, NJ: Princeton University Press.

Long, J. Scott. 1997. Regression Models for Categorical and Limited Dependent Variables. Thousand Oaks, CA: Sage.

Lotan, Gilad, Erhardt Graeff, Mike Ananny, Devin Gaffney, Ian Pearce, and Danah Boyd. 2011. 'The Revolutions Were Tweeted: Information Flows during the 2011 Tunisian and Egyptian Revolutions'. International Journal of Communication 5:1375-405.

Marshall, Monty G., Keith Jaggers, and Ted Robert Gurr. 2012. 'Polity IV Project: Dataset Users' Manual'. Vienna, VA: Center for Systemic Peace.

Maves, Jessica, and Alex Braithwaite. 2013. 'Autocratic Institutions and Civil Conflict Contagion'. Journal of Politics 75(2):478-90.

Midlarsky, Manus I., Martha Crenshaw, and Fumihiko Yoshida. 1980. 'Why Violence Spreads: The Contagion of International Terrorism'. International Studies Quarterly 24(2):262-98. 
Moore, Will H., and David R. Davis. 1998. 'Transnational Ethnic Ties and Foreign Policy'. In The International Spread of Ethnic Conflict: Fear, Diffusion, Escalation, edited by David A. Lake Donald Rothchild, 89-103. Princeton, NJ: Princeton University Press.

Murdoch, James C., and Todd Sandler. 2002. 'Economic Growth, Civil Wars, and Spatial Spillovers'. Journal of Conflict Resolution 46(1):91-110.

Myers, Daniel J. 2000. 'The Diffusion of Collective Violence: Infectiousness, Susceptibility, and Mass Media Networks'. American Journal of Sociology 106(1):173-208.

Neumayer, Eric, and Thomas Plümper. 2010. 'Galton's Problem and Contagion in International Terrorism along Civilizational Lines'. Conflict Management and Peace Science 27(4):308-25.

2011. 'Foreign Terror on Americans'. Journal of Peace Research 48(1):3-17. forthcoming. W. Political Science Research and Methods.

Pierskalla, Jan H., and Florian M. Hollenbach. 2013. 'Technology and Collective Action: The Effect of Cell Phone Coverage on Political Violence in Africa'. American Political Science Review 107(2):207-24.

Plümper, T., and E. Neumayer. 2010. 'Model Specification in the Analysis of Spatial Dependence'. European Journal of Political Research 49(3):418-42.

Posner, Daniel N. 2004. 'Measuring Ethnic Fractionalization in Africa'. American Journal of Political Science 48(4):849-63.

Salehyan, Idean, and Kristian Skrede Gleditsch. 2006. 'Refugees and the Spread of Civil War'. International Organization 60(2):335-66.

Salehyan, Idean, Cullen S. Hendrix, Jesse Hamner, Christina Case, Christopher Linebarger, Emily Stull, and Jennifer Williams. 2012. 'Social Conflict in Africa: A New Database'. International Interactions 38(2):503-11.

Shapiro, Jacob N., and Nils B. Weidmann. 2012. 'Is the Phone Mightier than the Sword? Cell Phones and Insurgent Violence in Iraq'. Working Paper.

Simmons, Beth A., Frank Dobbin, and Geoffrey Garrett. 2006. 'Introduction: The International Diffusion of Liberalism'. International Organization 60:781-810.

Stepanova, Ekaterina. 2011. 'The Role of Information Communication Technologies in the "Arab Spring"'. Ponars Eurasia Policy Memo (159):1-6.

Warren, Camber T. 2014. 'Not by the Sword Alone: Soft Power, Mass Media, and the Production of State Sovereignty'. International Organization. 68(1):111-41.

Weyland, Kurt Gerhard. 2005. 'Theories of Policy Diffusion: Lessons from Latin American Pension Reform'. World Politics 57(2):262-95.

Yanagizawa-Drott, David. 2012. 'Propaganda and Conflict: Theory and Evidence from the Rwandan Genocide'. Working Paper 257. Cambridge, MA: Center for International Development, Harvard University. 